\title{
Coaching Process Of Prisoners In Correctional Institution Class I Kedungpane Semarang Viewed From Act No 12 Of 1995 On Concerning The Correctional Institution
}

Antoni Muhamad Nur Cahyo ${ }^{1}$ and Achmad Sulchan ${ }^{2}$

Abstract. The problem this study are: a) how the coaching process in prison inmates Class 1 Kedungpane Semarang in terms of Act No. 12 of 1995 on Correctional Institution? and b) whether a limiting factor in the implementation of prison inmate gave coaching in the Correctional Institution Class I Kedungpane Semarang? Researchers using normative juridical approach. The source and type of data in this study are primary data obtained from field studies with interviews at the Correctional Institution Class I Kedungpane Semarang. And secondary data obtained from the study of literature. Based on the results of the implementation study coaching in the penal system for prisoners gradually form has been going well, the first stage of the introduction of the orientation stage where inmates including receiving prisoners, registration inmates and temporary placement of prisoners, the introduction of a maximum of 1 month. The second stage of assimilation in the strict sense lasts from $1 / 3$ to $1 / 2$. The third stage is the stage of assimilation in a broader sense and has lived half of a criminal past. The fourth stage is the stage of integration with the community has undergone criminal or $2 / 3$ of the time for at least 9 months. The obstacles that occur due to the lack of Correctional officer training, infrastructure is still lacking adequate. Addition of facilities are still related to education problem such as library books, any additional school, socializing with new science and training tools. Construction of shelter / blocks apart to make it more comfortable for them.

Keywords: Correctional Institution; Prisoners; Development.

\section{Introduction}

Penitentiary hereinafter abbreviated as Correctional Institution (LAPAS) is a place or residence for people who have been found guilty by the court that he had been found to violate of law. When someone has put in Correctional Institution, the rights of freedom as citizens will be revoked. He could no longer freely as people outside Correctional Institution. Understanding Penitentiary in Act No. 12 of 1995 Concerning the Penal Article 1 Paragraph (3) states that "Penitentiary hereinafter called Prison is the place to carry out coaching inmates and correctional". ${ }^{3}$ That Indonesia as a State of

\footnotetext{
${ }^{1}$ Student of Master of Law, Sultan Agung Islamic University (UNISSULA), Semarang Email: antonimuhamadnurcahyo@yahoo.com

${ }^{2}$ Lecturer of Master of Law, Sultan Agung Islamic University (UNISSULA), Semarang

${ }^{3}$ Act No. 12 of 1995 on Correctional Institution Article 1 Paragraph (3)
} 
Law in the application of punishment for prisoners, no longer wearing a penal system, but the penal system.4

Based on that idea, then since 1964 development system for inmates and criminal child has changed substantially, ie from the penal system into the correctional system. Similarly, the institution which was originally called home education home state prison and turned into Prison by virtue of instructions for the Chief Directorate of Corrections No. JHG8 / 506 on June 17, 1964. Changes in the term does not just eliminate the impression of scary and torture in the prison system, but rather to how provide humane treatment of inmates. ${ }^{5}$ Fostering criminal sanctions with inmates at the Correctional Institution in Indonesia experienced significant changes, especially on treatment of prisoners method itself. ${ }^{6}$

Based on the above exposure authors take the title research titled "Process coaching Against Prisoners in Penitentiary Class 1 Kedungpane Semarang Seen From the Law of the Republic of Indonesia Number 12 of 1995 On Socialization"

In this study, the problem is going to be discussed: What is the process guidance to inmates at the Correctional Institutions Class 1 Kedungpane Semarang Seen From the Law of the Republic of Indonesia Number 12 of 1995 On Correctional Institution?; What are the things that become obstacles in the process of formation of prisoners in Correctional Institutions Class I Kedungpane Semarang Seen From the Law of the Republic of Indonesia Number 12 of 1995 On Correctional Institution?

\section{Research methods}

To complete this study in order to be more focused and can be justified scientifically, then the writing method used, among others. ${ }^{7}$

The method used is namely sociological juridical The research was based on a legal provision and phenomena or events that occur in the field. Where his research type This is descriptive analysis means authors conducted a study that aims to give a comprehensive picture of the facts and the legal issues, the legal system related to the object of research, then pulled a certain belief took this to a conclusion. ${ }^{8}$

The analysis in this journal writing using Qualitative analysis techniques that is to say where the data obtained and compiled systematically so that it will be obtained a

\footnotetext{
${ }^{4}$ Dwidja Priyatno, Sitem Pelaksanaan Pidana Penjara Di Indonesia, Refika Aditama, Bandung, 2006, p. 3.

${ }^{5}$ Setia Hadi Tunggal, Undang-undang Pemasyarakatan beserta Peratura pelaksanaannya, Alumni Bandung, 2001, p. 253.

${ }^{6}$ DjismanSamosir, 1992, Fungsi Pidana Penjara Dalam Sistem Pemidanaan Di Indonesia, Bandung: BinaCipta, Hal.81

${ }^{7}$ Soejono Soekanto, Pengantar Penelitian Hukum, (Jakarta: UI Pres, 2015), p. 43

${ }^{8}$ Soerjono Soekanto and Sri Mamudji, Penelitian Hukum Normatif Suatu Tinjauan Singkat, (Jakarta: Raja Grafindo Persada, 20), p.14.
} 
comprehensive overview, in which the data will be presented in descriptive, With the expectation can be obtained comprehensive picture of the problems studied. ${ }^{9}$

\section{Results and Discussion}

\subsection{Implementation Process Guidance of Correctional Institutions Class 1 Kedungpane Semarang.}

\subsubsection{Personality Development Process Behave}

Fostering of the prisoners known as correctional. The aim of the penitentiary system is after prisoners follow the entire development program, it is expected they will realize their mistakes, improve themselves, and not to repeat the criminal act that can be received by the community, can play an active role in development, and can live naturally as citizens nice and responsible.

The period of introduction of the environment or the admission and orientation of an initial phase of construction of the prisoners. Once set in a block of residential or homestead respectively, inmates will be notified by officer of popularization of the order is in prison, the names of the officers as well as the whole staff of servants, duties and rights of inmates, how to make a complaint, and everything that exists in the Penitentiary Class I Kedungpane Semarang. The period of introduction of the environment (MAPENALING) were performed for 7 days (one week). It is desirable that inmates can adjust to adapt, so it is expected that inmates can adjust and adapt, so that it can interact normally in prison. At this stage, very strict control (maximum security).

Results of an interview with Mr. Fajar Sodik, served as Bimpas (Guidance correctional) Correctional Institution Class I Kedungpane Semarang on Monday, March 19, 2018 at 10:10 AM at the Correctional Institution Class I Kedungpane Semarang, process development conducted on the prisoners started the first time the prisoners entered Correctional Institution and then do a physical examination until at registration. The next stage, prisoners are placed in a special guesthouse to undergo the process Introduction to Environmental Future (MAPENALING) for 7 days (one week). After running MAPENALING process, the Citizens Patronage of Corrections will be input into a guesthouse for the next run coaching process, which is divided into:

- Stage of development, held on 1/3 (one third) to $1 / 2$ (one half) of a criminal past, at this stage do very strict supervision (maximum security).

- Assimilation phase, implementation is started $1 / 2$ (one half) to 2/3 (two thirds) of the criminal past. At this stage of development started inside prison or outside prison. To outside prison inmates with general criminal cases will be placed on

\footnotetext{
${ }^{9}$ Eko Sugiarto, Proposals Preparation Qualitative Research, Thesis and Thesis, (Yogyakarta: Asylum Media, 2015), p, 9.
} 
companies that wish to accommodate prisoners and earn wages. As for inmates with cases of criminal offenses Custom (Tipisus) particularly Corruption will do the work related to the social, which Citizens Patronage of Corrections is not rewarded because in economic terms is considered capable. At this stage supervision is somewhat reduced (medium security).

- Integration phase, implemented after the prisoners underwent 2/3 (two thirds) criminal past until the expiration of the criminal. At this stage the supervision has been significantly reduced (minimum security) Citizens. If Patronage of Corrections in value already good behavior undergoing training, then at this stage can be submitted remission, parole, conditional leave, and leave to visit family. All must pass through the filing process first and then will be determined through the court process.

Furthermore, Mr. Fajar Sodik explain the development patterns given to prisoners (WBP) include: Development The Religious Personality and Independence Development Process

Development The Religious Personality Covers:

- Development religious awareness or devotion to God Almighty Development of religious awareness training is considered the earliest to be followed by prisoners at the Correctional Institution Class I Kedungpane Semarang. In carrying out coaching in the religious field, at the Correctional Institution Class I Kedungpane Semarang worship facility and infrastructure such as: At-Taubah mosque of Correctional Institution Class I Kedungpane Semarang; Emanuel Church Penitentiary Class I Kedungpane Semarang

- Development of Legal Awareness

Since inmates committed a crime, they were considered not aware of the law or regulations, then when they are placed in Correctional Institution, prisoners are expected to be able to realize any applicable law or at least comply with the applicable regulations. Fostering awareness of the law to the prisoners (PLT) at the Correctional Institution Class I Kedungpane Semarang is the duty of all prisoners is no exception to obey and comply with all rules and regulations in force at the Correctional Institution Class I Kedungpane Semarang.

liabilities prisoners in addition to abide by and comply with all regulations at the Correctional Institution Class I Kedungpane Semarang is as follows: Observant religious worship in accordance with their individual belief and maintain religious harmony in the neighborhood Correctional Institution Class I Kedungpane Semarang; Following all the activities that have been programmed ; Submissive, obedient and respectful to all officers; Wearing uniforms that have been awarded; Maintain the neatness of dress in accordance with the norms of decency; Maintain personal and environmental hygiene occupancy ; Following the morning assembly 
which is lead by a security officer at $08: 00 \mathrm{pm}$; Following the morning exercise carried out every day are distinguished in the top of each homestead occupancy from $08.00 \mathrm{pm}$

- Development of Intellectual Capability

Development of intellectual abilities programmed Correctional Institution Class I Kedungpane Semarang is a program of English language courses, Penitentiary Class I Kedungpane Semarang in collaboration with Governmental Organization (NGO) that wants to give lessons English language courses to prisoners. English language courses should be followed by the prisoners, but in reality, not all inmates who want to follow the teaching of English, but inmates who are interested to know English.

- Physical And Spiritual Health Coaching

The results of interviews conducted by the author with the mrs. Okta as staff guidance and civic Penitentiary Class I Kedungpane Semarang on Thursday, 22 March 2018 at 10.00 hrs at the Correctional Institution Class I Kedungpane Semarang, fostering physical and mental health which is programmed at the Correctional Institution Class I Kedungpane Semarang is: 1) Ensuring the health of all prisoners; 2) Provision of a decent meal; 3) Means of sport as physical health support.

- Independence Development Process: Vocational Guidance and Training and Production.

Vocational Guidance : Development of the programmed job skills at the Correctional Institution Class I Kedungpane Semarang is the skill of making hand fans, sanding, and the making of handicrafts. Implemented in banker coaching or workshops Penitentiary Class I Kedungpane Semarang.

Training and Production, As well as coaching skills, vocational training and production workshops are also held at the Correctional Institution Class I Kedungpane Semarang mandatory prisoners.

\subsection{Obstacles in the Implementation Guidance of Prisoners}

Provision of adequate facilities at the Facilities of Correctional Institution be a very important factor in performing functions as a container Penitentiary guidance to inmates. In general the number of inmates at the Correctional Institution Class I Kedungpane Semarang had exceeded the proper capacity (over capacity). ${ }^{10}$ As a result of occupants exceed capacity at the Penitentiary, there Penitentiary children then half location used to accommodate the adult prisoners. In fact, there is also the Penitentiary which also accommodates adult male prisoners, female adult, arrest, and

${ }^{10}$ A Josias and R-Thomas Sunaryo, op.cit, hal.129. 
convict child. In some other Correctional Institution estimated the number of occupants exceeds the capacity is due to the many cases of drug abuse and gambling were arrested. ${ }^{11}$

In general, correctional institutions experienced some factors that can hinder the process of development, in addition to the imbalance of occupants to the Correctional Institution, a state of lack of funds for health are also found in some Penitentiary, among others, absence of clinics and doctors in Penitentiary. ${ }^{12}$ Problems in the body Penitentiary can not be resolved easily given the lack of funding to create new Correctional Institution and the limited land that could be used to create new Penitentiary. ${ }^{13}$

Conduct training for prisoners is not an easy thing and a challenge from time to time for each Penitentiary in Indonesia. Prison is prison or institution a very important role in the dissemination of returning prisoners as part of the end of the criminal justice system in Indonesia. The results of the interviews conducted by the author with Mr. Fajar Sodik on a Thursday, March 22, 2018 at 12:00 am, found several factors that can hinder the implementation of security systems and guidance to prisoners such as: Unbalance amount Penitentiary security officer Class I Kedungpane Semarang with the number of prisoners, so the implementation of the security system to be not optimal; and Limited facilities and infrastructure that supports security at the Correctional Institution Class I Kedungpane Semarang such as the lack of the number of security cameras (CCTV), and the lack of security weapons for security officers Correctional Institution Class I Kedungpane Semarang.

Furthermore, Mr. Fajar Sodik on a Thursday, March 22, 2018 at 12:00 am, said other factors inhibiting the Class I Correctional Institution Kedungpane Semarang. That is :

- State Penitentiary Class I Kedungpane Semarang experiencing over capacity (the capacity is inadequate compared to the number Penitentiary prisoners). Prison has a capacity of a capacity of 510 people, while the number of prisoners at the Correctional Institution Class I Kedungpane Semarang until now amounted to 1337 people.

- Not all prisoners are willing to follow the guidance that is programmed at the Correctional Institution Class I Kedungpane Semarang.

- Facilities and infrastructure that support the development process.

- Lack of teachers coaching

- Lack of welfare level felt by residents Patronage of Corrections.

\footnotetext{
${ }^{11}$ Ibid., p. 30

${ }^{12}$ lbid.

${ }^{13}$ Ibid.
} 


\section{Closing}

\subsection{Conclusions}

Based on the description as mentioned above, it can be concluded as follows:

- Conditions correctional supervision on Citizens Patronage at the Correctional Institution Class I Kedungpane Semarang can be said is not running optimally. This is evidenced by the limited facilities and infrastructure support coaching program, state Correctional Institution are experiencing over capacity, not all prisoners are willing to follow the coaching program, The number of prisoners who use drugs and are still a lot of the discovery of the prisoners who use mobile phones (Telephone handheld) in in prison, so that the correctional system is not going well at the correctional Institution Class I Kedungpane Semarang.

- To achieve the objectives of the correctional system required by Article 2 and Article 3 of Act No. 12 of 1995 on Corrections, then efforts should be made to the coaching inmates in Correctional Institution Class I Kedungpane Semarang, namely: a reduction in the amount of circulation of money in Correctional Institution with the card manufacturing of brezzi, placement of prisoners based on the case, dissemination to the public in order to change the stigma against prisoners, so that the former inmates to reintegrated into society.

\section{Suggestions}

- Inmates serving sentences under three months should not be placed in the Penitentiary, but by rehabilitating somewhere to move the prisoners that are outside the Penitentiary Class I Kedungpane Semarang that overcapacity in Penitentiary Class I Kedungpane can Semarang overcome.

- Required additional field security officers and security devices such as surveillance cameras (CCTV), and securing weapons at the Correctional Institution Class I Kedungpane Semarang for the implementation guidance to prisoners can be run with the maximum and there will be violations or irregularities.

\section{References}

[1] A Josias and R-Thomas Sunaryo, "Studi Kebudayaan Lembaga Pemasyarakatan Di Indonesia ". Bandung: Lubuk Agung 2010.

[2] Dwidja Priyatno, Sitem Pelaksanaan Pidana Penjara Di Indonesia, Refika Aditama, Bandung, 2013.

[3] Eko Sugiarto, Menyusun Proposal Penelitian Kualitatif, Skripsi dan Tesis, (Yogyakarta: Asylum Media, 2015). 
[4] Single Setia Hadi, Undang-undang Pemasyarakatan beserta Peraturan pelaksanaannya, Alumni Bandung 2011.

[5] Lidya Suryani Widayawati, ," Rehabilitasi Narapidana Dalam Overcrowded Lembaga Pemasyarakatan" Negara Hukum Vol.3, No.2, 2012. url: https // jurnal.dpr.go.id / index.php / law / article / view / 231/172.

[6] Nawawi Arief, Barda, 2010, "Kebijakan Legislatif Dalam Penanggulangan Kejahatan Dengan Pidana Penjara".Yogyakarta: Genta Publishing.

[7] Rugun Romaida Hutabarat, ,"Problematika Lembaga Pemasyarakatan Dalam Sistem Peradilan Terpadu", Jurnal Muara Ilmu Sosial,Humaniora,dan Seni Vol.1, No.1, April 2017. url: https://journal.untar.ac.id/index.php/jmis,

[8] Soejono Soekanto, 2015, Pengantar Penelitian Hukum, UI Pres, Jakarta.

[9] Soerjono Soekanto and Sri Mamudji, 2015, Penelitian Hukum Normatif Suatu Tinjauan Singkat, Raja Grafindo Persada Jakarta. 